\title{
Effects of different restricted feeding strategies on performance of growing and finishing dairy bulls offered grass silage and barley based diets
}

\author{
Katariina Manni ${ }^{1}$, Marketta Rinne ${ }^{2}$, Erkki Joki-Tokola ${ }^{3}$, Arto Huuskonen ${ }^{3}$ \\ ${ }^{1}$ Häme University of Applied Sciences, Fl-31310 Mustiala, Finland \\ ${ }^{2}$ Natural Resources Institute Finland (Luke), Green Technology, Fl-31600 Jokioinen, Finland \\ ${ }^{3}$ Natural Resources Institute Finland (Luke), Green Technology, FI-92400 Ruukki, Finland \\ e-mail: katariina.manni@hamk.fi
}

\begin{abstract}
The objective of this study was to determine the effects of restricted feeding strategies on performance of growing and finishing dairy bulls. The feeding experiment comprised in total 32 Finnish Ayrshire bulls with an initial mean live weight (LW) of $122 \mathrm{~kg}$ and age of 114 days. Feeding treatments were silage ad libitum and daily barley allowance of $93 \mathrm{~g}$ dry matter $\mathrm{kg}^{-1} \mathrm{LW}^{0.60}(\mathrm{~A})$; restricted feeding $(\mathrm{R})$ at $0.80 \times \mathrm{A}$; increasing feeding (I) similar to $\mathrm{R}$ until $\mathrm{LW}$ of $430 \mathrm{~kg}$ and thereafter similar to A; and decreasing feeding (D) similar to A until LW of $430 \mathrm{~kg}$ and thereafter similar to R. Restricted feeding strategies decreased daily dry matter intake and LW gain and increased the time to reach the target carcass weight $(300 \mathrm{~kg})$. Bulls on I exhibited compensatory growth. There were no significant differences in dry matter or energy efficiency between the treatments. The present experiment indicates that silage intake $a d$ libitum and supplemented with concentrate resulted in most effective beef production.
\end{abstract}

Key words: beef production, growth, compensatory growth, feed efficiency

\section{Introduction}

Economic profitability is one of the principal challenges in beef production and it is important to assess innovative production methods to improve it. In general, feed costs are a major proportion of total variable costs in most beef systems (French et al. 2001a, 2001b). Reducing them without diminishing animal performance would improve profitability of beef production. Different feeding strategies may, however, affect substantially animal performance (Keane et al. 2006, Huuskonen et al. 2007, Manni et al. 2013).

Restricted feed intake is one method to potentially improve feed conversion rate and thus reduce feeding costs. In some experiments, restricted feed intake either during the growing period (Knoblich et al. 1997; Trial 1, Rossi et al. 2001; Trial 1) or growing and finishing period (Hicks et al. 1990; Trial 1, Murphy and Loerch 1994; Trial 2) has improved feed efficiency. Suggested reasons for this are increased diet digestibility, reduced feed waste and animal activity and decreased size of visceral organs, which reduce energy requirement for maintenance (Hicks et al. 1990).

Growth pattern may influence carcass quality, conformation and especially fatness, which has economic significance in beef production depending on the pricing systems used. In Finland, consumers generally favour low-fat products. In addition, high-fat carcasses cause additional expenditures for the meat industry (Herva et al. 2011). In consequence, lean carcasses are favoured in the pricing and there are penalties for fat carcasses. For these reasons, carcass fat score is an important production parameter affecting the profitability of farms and the entire beef chain. In addition, excessive fat accumulation decreases the efficiency of feed utilization (Murphy and Loerch 1994). By using partially restricted growth during the fattening period it is possible to produce lower-fat and increased conformation carcasses (Carstens et al. 1991).

If growth rate of growing cattle is manipulated with feed restriction and subsequent realimentation, growth rate typically accelerates and animals exhibit compensatory growth. It enables animals to catch up to the weight of animals whose growth was not restricted. However, full recovery is scarcely observed (Hornick et al. 2000). Incorporating a period of feed restriction during the growing phase and then increasing feeding during the finishing phase can improve growth and feed efficiency (Knoblich et al. 1997; Trial 1, Rossi et al. 2001; Trial 1), reduce total dry matter (DM) intake (DMI) and in consequence cut feeding costs (Knoblich et al. 1997; Trial 1) and reduce carcass fatness (Wright and Russel 1991, Rossi et al. 2001; Trial 1, Manni et al. 2013). However, experiments of compensatory growth have given conflicting results on animal performance, feed intake and carcass composition (Rompala et al. 1985, Sainz et al. 1995, Knoblich et al. 1997, Manni et al. 2013, Keogh et al. 2015). 
Although the mechanisms of compensatory growth and its consequences for animal performance have been studied in several experiments (Sainz et al. 1995, Rossi et al. 2001, Manni et al. 2013), still many aspects of this phenomenon are poorly understood.

The implications of compensatory growth are important in beef production systems, which are based on restricted feed and/or nutrient intake during winter and then access to high quality pasture during grazing season, or where calves are raised in semi-natural low quality pasture and finished intensively in feedlots. In intensive beef production systems, such as in Nordic countries, animals are confined during the whole growing period. Feeding is based on ad libitum grass silage intake which is supplemented with grain. In this kind of system, compensatory growth is currently not used and the possible benefits of it are unclear.

The objective of this experiment was to determine the effects of feed allocation regime on the performance of growing dairy bulls to achieve steady, increased or decreased growth pattern.

It was hypothesized that:

1) Ad libitum silage intake supplemented with concentrate improves growth and carcass conformation compared to restricted feeding strategies.

2) Increasing and decreasing feeding strategies result in different growth patterns of the bulls but their average growth rates do not differ over the whole experimental period.

3) Increasing DMI during the late part of the growing period results in compensatory growth.

4) Restricted feeding during part or whole growing period improves the average feed conversion rate and reduces fatness compared to unrestricted feeding.

\section{Materials and methods \\ Animals and housing}

A feeding experiment was conducted in the experimental barn of Natural Resources Institute Finland (Luke) in Ruukki, Finland. Animals were managed according to the Finnish legislation regarding the use of animals in scientific experimentation. The experiment comprised in total 32 Finnish Ayrshire bulls. All animals were purchased from local dairy farms with an initial live weight $(\mathrm{LW})$ of $58( \pm 4.1) \mathrm{kg}$ and age of $44( \pm 6.9)$ days. In the pre-experimental period the calves were housed in an insulated barn and fed milk replacer, hay, grass silage and concentrates (rolled barley and rapeseed meal).

At the beginning of the feeding experiment the animals with average age of 114 days and LW of $123( \pm 8.9) \mathrm{kg}$ were divided into eight blocks of four animals by LW. Within the block the animals were randomly allotted to one of four treatments (eight bulls per treatment). The bulls were placed in an insulated barn in adjacent tie-stalls and fed individually. The width of the stalls was 70-90 cm for the first six months and $113 \mathrm{~cm}$ until the end of the experiment. The bulls were tied with a collar around the neck, and $50 \mathrm{~cm}$ long chain was attached to a horizontal bar 40-55 cm above the floor. The floor surface was solid concrete under the forelegs and metal grids under the hind legs. No bedding was used on the floor. The animals were fed three times per day (at 0800, 1200 and 1800 hours). Refused feed was collected and measured at 0700 daily. All bulls were healthy throughout, and all completed the entire study.

\section{Feeding management and experimental design}

The feeding treatments consisted of four feed allocation regimes:

A: Ad libitum feeding. Ad libitum (daily proportionate refusals of $10 \%$ ) grass silage allowance during the whole experimental period. The amount of rolled barley grain supplementation was $93 \mathrm{~g} \mathrm{DM} \mathrm{kg}^{-1} \mathrm{LW}^{0.60}$ per animal per day during the whole experimental period.

R: Restricted feeding. Restricted grass silage and barley grain allowance during the whole experimental period, equivalent to $80 \%$ of group $\mathrm{A}$ intake at corresponding LW. 
I: Increasing feeding. Feeding similarly as group R up to $430 \mathrm{~kg} \mathrm{LW}$. After that (from $430 \mathrm{~kg}$ LW to slaughter) feeding similarly as group A.

D: Decreasing feeding. Feeding similarly as group A up to $430 \mathrm{~kg}$ LW. After that (from $430 \mathrm{~kg}$ LW to slaughter) feeding similarly as group $\mathrm{R}$.

The amount of concentrate was adjusted individually at intervals of approximately 14 days. It was based on LW for each weighing and between two consecutive weighing LW was calculated by live weight gain.

Grass silage and rolled barley grain were offered separately. The daily ration for the bulls included also $100 \mathrm{~g}$ of a mineral-vitamin mixture (Suomen Rehu Ltd., Finland: Seleeni Hertta-Minera muro: Ca 200, P 50, Na 70, Mg 70 g $\mathrm{kg}^{-1}$ ) and animals had free access to water from an open water bowl.

Grass silage was produced at the experimental farm of Luke in Ruukki $\left(64^{\circ} 44^{\prime} \mathrm{N}, 25^{\circ} 15^{\prime} \mathrm{E}\right)$. The silage was prepared from a timothy (Phleum pratense) and meadow fescue (Festuca pratensis) sward, cut at heading stage of timothy using a mower without conditioning, slightly wilted, harvested using a precision-chop forage harvester, treated with a formic acid based additive (AIV-2 Plus; Eastman Chemical Company, Oulu, Finland: $760 \mathrm{~g}$ formic acid kg-1, $55 \mathrm{~g}$ ammonium formate $\mathrm{kg}^{-1}$ ) applied at a rate of 5 litres $\mathrm{t}^{-1}$ of fresh grass and ensiled in bunker silos. Several silage batches were used during the course of the experiment.

\section{Feed sampling and analysis}

Silage sub-samples were taken twice a week, pooled over periods of four weeks and stored at $-20^{\circ} \mathrm{C}$ prior to analyses. Thawed samples were analysed for DM, ash, crude protein (CP), neutral detergent fibre (NDF), silage fermentation quality $[\mathrm{pH}$, lactic and formic acids, volatile fatty acids (VFA), soluble and ammonia $\mathrm{N}$ content of total $\mathrm{N}$ ] and digestible organic matter in DM (D-value). Barley sub-samples were collected weekly, pooled over periods of eight weeks and analysed for DM, ash, CP and NDF.

Fresh silage samples were analysed for fermentation quality by electrometric titration as described by Moisio and Heikonen (1989). The DM concentration was determined by drying at $105^{\circ} \mathrm{C}$ for $20 \mathrm{~h}$. Samples for chemical analyses were dried at $60^{\circ} \mathrm{C}$ for $16 \mathrm{~h}$ and milled using sample mill (Sakomylly KT-3100, Koneteollisuus Oy, Helsinki, Finland) using a $1 \mathrm{~mm}$ sieve. Oven DM concentration of silage samples was corrected for the loss of volatiles according to Huida et al. (1986). Silage and barley $\mathrm{N}$ was measured by the Kjeldahl method, and the CP concentration was calculated as $\mathrm{N} \times 6.25$. The organic matter concentration was determined by ashing at $600{ }^{\circ} \mathrm{C}$ for $2 \mathrm{~h}$. The NDF concentration was measured as described by Van Soest et al. (1991). Sodium sulphite was used in neutral detergent solution and $\alpha$-amylase in case of samples containing starch and NDF is expressed without containing residual ash. The silage samples were analysed for D-value as described by Huhtanen et al. (2006). The pepsincellulase solubility values were converted to in vivo digestibility using correction equations based on a data set comprising of Finnish in vivo digestibility trials (Huhtanen et al. 2006).

The metabolisable energy (ME) concentration of the silage was calculated as $0.016 \times \mathrm{D}$-value and for barley based on chemical composition (MAFF 1984). Crude fibre and crude fat concentrations and digestibility coefficients of barley grain were taken from the Finnish Feed Tables (Luke 2017). Metabolisable protein (MP) and protein balance in rumen (PBV) values were calculated according to the Finnish feed protein evaluation system (Luke 2017) in which PBV describes the balance between the dietary supply of rumen-degradable protein and the microbial requirements for rumen-degradable protein.

\section{Weighing, slaughter procedures and carcass quality measurements}

The bulls were weighed on two consecutive days at the beginning of the experiment and thereafter single weightings were done approximately every 28 days. The animals were weighed at two previous days before slaughtering. The LW at the end of the experiment was calculated as average of these two weightings. The target for average carcass weight in the present experiment was $300 \mathrm{~kg}$. The bulls were selected for slaughter based on LW and estimated carcass weight, and slaughtered in five batches.

The LW gain (LWG) was calculated as the difference between the means of the initial and final LW divided by the number of growing days. The estimated rate of carcass gain was calculated as the difference between the final cold carcass weight and the carcass weight at the beginning of the experiment divided by the number of growing days. The carcass weight at the start of the experiment was assumed to be $0.50 \times$ initial LW based on earlier studies (unpublished data). 
The animals were slaughtered in the Atria Ltd. commercial slaughterhouse in Kuopio, Finland. After slaughter the carcasses were weighed hot. The cold carcass weight was estimated as 0.98 of the hot carcass weight. Dressing proportion was calculated from the ratio of cold carcass weight to final LW. The carcasses were classified for conformation and fatness using the EUROP quality classification (EC 2006). For conformation, the development of the carcass profiles, in particular the essential parts (round, back, shoulder), was taken into consideration according to the EUROP classification (E: excellent, U: very good, R: good, O: fair, P: poor). Each level of the conformation scale was subdivided into three sub-classes to produce a transformed scale ranging from 1 to 15 , with 15 being the best conformation. For fat cover degree, the amount of fat on the outside of the carcass and in the thoracic cavity was taken into account using a classification range from 1 to 5 (1: low, 2: slight, 3: average, 4: high, 5: very high).

\section{Statistical methods}

The results are shown as least squares means. The normality of analysed variables was checked using graphical methods: box-plot and scatter plot of residuals and fitted values. The data were subjected to analysis of variance using the SAS GLM procedure (version 9.4, SAS Institute Inc., Cary, NC). The statistical model used was $\mathrm{y}_{\mathrm{ijkl}}=\mu+\beta_{\mathrm{j}}$ $+\gamma_{k}+\alpha_{i}+e_{i j k l}$, where $\mu$ is the intercept and $e_{i j k l}$ is the random error term associated with $\mathrm{t}^{\text {th }}$ animal. $\alpha_{i}$ is the fixed effect of the dietary treatment $(i=1,2,3,4)$ while $\beta_{i}$ and $\gamma_{k}$ are random effects of the block $(j=1, \ldots, 8)$ and the slaughtering batch $(k=1, \ldots, 5)$, respectively. The slaughtering batch was used in the model only for carcass measurements.

The differences between the treatments were tested using Tukey's test. The differences were considered statistically significant when $p<0.05$, which is used when presenting the results in the tables. Tendency of the statistical significances, $p<0.10$, is used only in the text.

\section{Results}

\section{Feeds and feed intake}

The chemical composition and feed values of the experimental feeds are presented in Table 1. The grass silage used was of average nutritional quality (i.e. metabolisable energy $10.4 \mathrm{MJ} \mathrm{kg}^{-1} \mathrm{DM}$ and MP $81 \mathrm{~g} \mathrm{~kg}^{-1} \mathrm{DM}$ ). The fermentation characteristics of the silage were good as indicated by the low $\mathrm{pH}$ value and the low concentration of ammonia $\mathrm{N}$ and VFA. The barley had a typical chemical composition and feed values, corresponding to the average values in the Finnish Feed Tables (Luke 2017).

Table 1. Chemical composition and feed values of grass silage and barley grain used in the feeding experiment

\begin{tabular}{lcc}
\hline & Grass silage & Barley grain \\
\hline Number of feed samples & 17 & 9 \\
Dry matter (DM), g kg-1 & $306 \pm 33.5$ & $881 \pm 8.9$ \\
In DM, g kg-1 DM & & $974 \pm 1.1$ \\
Organic matter & $921 \pm 4.1$ & $130 \pm 11.0$ \\
Crude protein & $161 \pm 9.7$ & $211 \pm 9.4$ \\
Neutral detergent fibre & $575 \pm 21.9$ & $13.0 \pm 0.29$ \\
Digestible organic matter & $652 \pm 14.6$ & $92 \pm 1.7$ \\
Metabolisable energy, $\mathrm{MJ} \mathrm{kg}^{-1} \mathrm{DM}$ & $10.4 \pm 0.23$ & $-9 \pm 8.5$ \\
Metabolisable protein & $81 \pm 2.4$ & \\
Protein balance in the rumen & $42 \pm 7.4$ & \\
Fermentation quality of silage & & \\
pH & & \\
Lactic + formic acid, g kg-1 DM & $3.95 \pm 0.090$ & \\
Volatile fatty acids, g kg-1 DM & $47 \pm 8.1$ & \\
Ammonia nitrogen, $\mathrm{g} \mathrm{kg}^{-1} \mathrm{~N}$ & $42 \pm 3.7$ & \\
Soluble nitrogen, $\mathrm{gg}^{-1} \mathrm{~N}$ & $42 \pm 9.4$ & \\
\hline
\end{tabular}


The average DM, ME and nutrient intakes of the bulls during the whole experimental period are presented in Table 2 and intakes divided into early and late period in Tables 3 and 4. When DMI was restricted either during the whole growing period (R) or in the early (I) or late (D) part of it, average daily DMI decreased 27,14 and $10 \%$ $(p<0.05)$, respectively, compared to treatment $A$ when the whole growing period was observed. The actual restriction of silage intake was more severe than targeted in R, I and D. In consequence of decreased DMI, ME, CP and MP intakes and PBV also decreased $(p<0.05)$. When comparing I to D over the whole growing period, there were no differences in average daily silage DMI but in I barley and total DMI were 8 and $5 \%$ lower $(p<0.05)$, respectively.

Table 2. Intake, gain, feed conversion rate and carcass characteristics of bulls fed with different feed allocation regimes over the total experimental period

\begin{tabular}{|c|c|c|c|c|c|c|}
\hline Treatments & $A^{1}$ & $\mathrm{R}^{2}$ & $1^{3}$ & $\mathrm{D}^{4}$ & SEM $^{5}$ & $p$-value ${ }^{6}$ \\
\hline Number of observations & 8 & 8 & 8 & 8 & - & - \\
\hline Duration of the experiment, $d$ & $377^{d}$ & $494^{\mathrm{a}}$ & $464^{b}$ & $409^{c}$ & 7.6 & $<0.001$ \\
\hline \multicolumn{7}{|l|}{ Intake } \\
\hline Silage, kg dry matter (DM) $\mathrm{d}^{-1}$ & $4.41^{\mathrm{a}}$ & $3.04^{c}$ & $3.83^{b}$ & $3.95^{b}$ & 0.066 & $<0.001$ \\
\hline Barley grain, kg DM d ${ }^{-1}$ & $3.13^{\mathrm{a}}$ & $2.46^{d}$ & $2.63^{c}$ & $2.85^{b}$ & 0.022 & $<0.001$ \\
\hline Mineral-vitamin mixture, $\mathrm{kg} \mathrm{DM} \mathrm{d}^{-1}$ & 0.09 & 0.09 & 0.09 & 0.09 & - & - \\
\hline Total, kg DM d ${ }^{-1}$ & $7.63^{\mathrm{a}}$ & $5.59^{c}$ & $6.55^{d}$ & $6.89^{b}$ & 0.079 & $<0.001$ \\
\hline Silage, g DM kg-1 $\mathrm{LW}^{0.60}$ & $131^{\mathrm{a}}$ & $92^{c}$ & $112^{\mathrm{b}}$ & $120^{b}$ & 2.0 & $<0.001$ \\
\hline Barley, g DM kg ${ }^{-1} \mathrm{LW}^{0.60}$ & $93^{\mathrm{a}}$ & $75^{\mathrm{c}}$ & $76^{c}$ & $86^{\mathrm{b}}$ & 0.6 & $<0.001$ \\
\hline Total DM, $\mathrm{g} \mathrm{kg}^{-1} \mathrm{LW}^{0.60}$ & $227^{\mathrm{a}}$ & $169^{d}$ & $191^{c}$ & $208^{b}$ & 2.4 & $<0.001$ \\
\hline Total silage, kg DM & $1663^{b}$ & $1502^{c}$ & $1777^{a}$ & $1616^{\mathrm{b}}$ & 44.8 & 0.002 \\
\hline Total barley, kg DM & 1180 & 1215 & 1220 & 1166 & 28.9 & 0.393 \\
\hline Metabolisable energy (ME), MJ d ${ }^{-1}$ & $87.3^{\mathrm{a}}$ & $63.6^{d}$ & $74.0^{c}$ & $78.6^{\mathrm{b}}$ & 0.86 & $<0.001$ \\
\hline Crude protein $(\mathrm{CP}), \mathrm{g} \mathrm{d}^{-1}$ & $1121^{\mathrm{a}}$ & $814^{d}$ & $962^{c}$ & $1011^{b}$ & 12.2 & $<0.001$ \\
\hline Metabolisable protein, $\mathrm{g} \mathrm{d}^{-1}$ & $648^{\mathrm{a}}$ & $472^{d}$ & $550^{c}$ & $583^{b}$ & 6.6 & $<0.001$ \\
\hline Protein balance in the rumen, $\mathrm{g} \mathrm{d}^{-1}$ & $154^{\mathrm{a}}$ & $109^{c}$ & $140^{\mathrm{b}}$ & $140^{\mathrm{b}}$ & 2.7 & $<0.001$ \\
\hline \multicolumn{7}{|l|}{ Live weight (LW), kg } \\
\hline At the beginning of the experiment & 124 & 123 & 122 & 122 & 1.2 & 0.838 \\
\hline At the end of the experiment & $578^{\mathrm{ab}}$ & $559^{b}$ & $604^{\mathrm{a}}$ & $559^{b}$ & 7.5 & 0.001 \\
\hline \multicolumn{7}{|l|}{ Age, $d$} \\
\hline At the beginning of the experiment & 113 & 114 & 114 & 115 & 1.0 & 0.845 \\
\hline At the end of the early part & $357^{b}$ & $463^{a}$ & $463^{\mathrm{a}}$ & $359^{b}$ & 1.0 & $<0.001$ \\
\hline At the end of the late part & $490^{d}$ & $607^{a}$ & $577^{\mathrm{b}}$ & $524^{c}$ & 7.6 & $<0.001$ \\
\hline Live weight gain (LWG), $\mathrm{g} \mathrm{d}^{-1}$ & $1209^{a}$ & $884^{c}$ & $1041^{b}$ & $1073^{b}$ & 17.8 & $<0.001$ \\
\hline Carcass gain, $\mathrm{g} \mathrm{d}^{-1}$ & $628^{\mathrm{a}}$ & $480^{c}$ & $544^{\mathrm{b}}$ & $575^{b}$ & 10.7 & $<0.001$ \\
\hline \multicolumn{7}{|l|}{ Feed conversion rate } \\
\hline $\mathrm{Kg} \mathrm{DM} \mathrm{kg}^{-1} \mathrm{LWG}$ & 6.31 & 6.32 & 6.29 & 6.42 & 0.131 & 0.908 \\
\hline $\mathrm{Kg} \mathrm{DM} \mathrm{kg}^{-1}$ carcass gain & 12.15 & 11.65 & 12.04 & 11.98 & 0.240 & 0.544 \\
\hline MJ ME kg-1 LWG & 72.2 & 71.9 & 71.1 & 73.3 & 1.45 & 0.772 \\
\hline MJ ME kg-1 carcass gain & 139.0 & 132.5 & 136.0 & 136.7 & 2.65 & 0.427 \\
\hline g CP kg-1 LWG & 927 & 921 & 924 & 942 & 19.6 & 0.564 \\
\hline $\mathrm{g} \mathrm{CP} \mathrm{kg}^{-1}$ carcass gain & 1785 & 1696 & 1768 & 1758 & 35.9 & 0.375 \\
\hline \multicolumn{7}{|l|}{ Carcass characteristics } \\
\hline Carcass weight, kg & 298 & 298 & 313 & 296 & 4.8 & 0.052 \\
\hline Dressing proportion, $\mathrm{g} \mathrm{kg}^{-1}$ & 515 & 534 & 519 & 529 & 6.4 & 0.098 \\
\hline Conformation score, EUROP & 4.5 & 4.0 & 3.9 & 4.4 & 0.19 & 0.081 \\
\hline Fat score, EUROP & $2.8^{\mathrm{a}}$ & $2.0^{\mathrm{b}}$ & $2.4^{\mathrm{ab}}$ & $2.3^{\mathrm{ab}}$ & 0.14 & 0.012 \\
\hline
\end{tabular}

${ }^{1} \mathrm{~A}=$ Ad libitum grass silage allowance during the whole experimental period. The amount of the barley grain supplementation was $93 \mathrm{~g} \mathrm{DM} \mathrm{kg}^{-1} \mathrm{LW}^{0.60}$ per animal per day during the whole experimental period. ${ }^{2} \mathrm{R}=$ Restricted silage and barley allowance $(0.8$ $\times$ treatment $A$ intake) during the whole experimental period. ${ }^{3}$ I = Feeding similarly as group $R$ up to $430 \mathrm{~kg} L W$. After that, feeding similarly as group A. ${ }^{4} \mathrm{D}=$ Feeding similarly as group A up to $430 \mathrm{~kg}$ LW. After that, feeding similarly as group R. ${ }^{5} \mathrm{SEM}=\mathrm{Standard}$ error of the mean. ${ }^{6}$ Means in the same row with different superscript letters are significantly different $(p<0.05)$. 
K. Manni et al. (2017) 26: 91-101

Table 3. Intake, gain and feed conversion rate of the bulls during the early part of the growing period (up to $430 \mathrm{~kg}$ live weight [LW])

\begin{tabular}{|c|c|c|c|c|c|c|}
\hline Treatments & $A^{1}$ & $\mathrm{R}^{2}$ & $1^{3}$ & $\mathrm{D}^{4}$ & SEM $^{5}$ & $p$-value ${ }^{6}$ \\
\hline Number of observations & 8 & 8 & 8 & 8 & - & - \\
\hline Duration of the period, $d$ & $244^{\mathrm{a}}$ & $349^{b}$ & $349^{b}$ & $244^{a}$ & 7.6 & $<0.001$ \\
\hline \multicolumn{7}{|l|}{ Intake } \\
\hline Silage, kg dry matter (DM) $d^{-1}$ & $3.86^{\mathrm{a}}$ & $2.80^{b}$ & $2.85^{b}$ & $3.80^{\mathrm{a}}$ & 0.076 & $<0.001$ \\
\hline Barley grain, kg DM d ${ }^{-1}$ & $2.68^{a}$ & $2.16^{\mathrm{b}}$ & $2.18^{b}$ & $2.62^{a}$ & 0.022 & $<0.001$ \\
\hline Mineral-vitamin mixture, $\mathrm{kg} \mathrm{DM} \mathrm{d}^{-1}$ & 0.09 & 0.09 & 0.09 & 0.09 & - & - \\
\hline Total, kg DM d ${ }^{-1}$ & $6.63^{a}$ & $5.05^{b}$ & $5.12^{b}$ & $6.51^{a}$ & 0.090 & $<0.001$ \\
\hline Silage, g DM kg-1 LW $^{0.60}$ & $131^{\mathrm{a}}$ & $96^{b}$ & $97^{b}$ & $129^{a}$ & 2.3 & $<0.001$ \\
\hline Barley, g DM kg-1 LW ${ }^{0.60}$ & $93^{a}$ & $74^{b}$ & $74^{b}$ & $93^{a}$ & 0.6 & $<0.001$ \\
\hline Total DM, g kg LW $^{0.60}$ & $226^{a}$ & $172^{b}$ & $174^{b}$ & $224^{a}$ & 2.6 & $<0.001$ \\
\hline Total silage, kg DM & 942 & 977 & 995 & 927 & 20.5 & 0.092 \\
\hline Total barley, kg DM & $654^{b}$ & $754^{a}$ & $761^{\mathrm{a}}$ & $640^{b}$ & 6.2 & $<0.001$ \\
\hline Metabolisable energy (ME), MJ d $\mathrm{d}^{-1}$ & $76.0^{\mathrm{a}}$ & $57.9^{b}$ & $58.6^{b}$ & $74.5^{\mathrm{a}}$ & 0.99 & $<0.001$ \\
\hline Crude protein $(C P), g^{-1}$ & $918^{a}$ & $691^{b}$ & $701^{b}$ & $900^{a}$ & 13.5 & $<0.001$ \\
\hline Metabolisable protein, $\mathrm{g} \mathrm{d}^{-1}$ & $563^{a}$ & $427^{b}$ & $433^{b}$ & $552^{a}$ & 7.5 & $<0.001$ \\
\hline Protein balance in the rumen, $\mathrm{g} \mathrm{d}^{-1}$ & $115^{\mathrm{a}}$ & $70^{b}$ & $72^{b}$ & $113^{a}$ & 3.2 & $<0.001$ \\
\hline Live weight gain (LWG), $\mathrm{g} \mathrm{d}^{-1}$ & $1280^{\mathrm{a}}$ & $880^{b}$ & $898^{b}$ & $1295^{\mathrm{a}}$ & 25.5 & $<0.001$ \\
\hline \multicolumn{7}{|l|}{ Feed conversion rate } \\
\hline $\mathrm{Kg} \mathrm{DM} \mathrm{kg}^{-1}$ LWG & $5.18^{b}$ & $5.74^{\mathrm{a}}$ & $5.70^{\mathrm{a}}$ & $5.03^{b}$ & 0.108 & $<0.001$ \\
\hline MJ ME kg ${ }^{-1}$ LWG & $59.4^{b}$ & $65.8^{\mathrm{a}}$ & $65.3^{\mathrm{a}}$ & $57.5^{b}$ & 1.22 & $<0.001$ \\
\hline g CP kg-1 LWG & $719^{b}$ & $788^{a}$ & $782^{\mathrm{a}}$ & $695^{b}$ & 15.1 & $<0.001$ \\
\hline
\end{tabular}

${ }^{1} \mathrm{~A}=$ Ad libitum grass silage allowance during the whole experimental period. The amount of the barley grain supplementation was $93 \mathrm{~g} \mathrm{DM} \mathrm{kg}^{-1} \mathrm{LW}^{0.60}$ per animal per day during the whole experimental period. ${ }^{2} \mathrm{R}=$ Restricted silage and barley allowance $(0.8 \times$ treatment $A$ intake $)$ during the whole experimental period. ${ }^{3} \mathrm{I}=$ Feeding similarly as group $\mathrm{R}$ up to $430 \mathrm{~kg} \mathrm{LW}$. After that, feeding similarly as group A. ${ }^{4} \mathrm{D}=$ Feeding similarly as group $\mathrm{A}$ up to $430 \mathrm{~kg} \mathrm{LW}$. After that, feeding similarly as group R. ${ }^{5} \mathrm{SEM}$ $=$ Standard error of the mean. ${ }^{6}$ Means in the same row with different superscript letters are significantly different $(p<0.05)$.

Table 4. Intake, gain and feed conversion rate of the bulls during the late part of the growing period (430 kg live weight [LW] to slaughter)

\begin{tabular}{|c|c|c|c|c|c|c|}
\hline Treatments & $A^{1}$ & $\mathrm{R}^{2}$ & $\mathrm{I}^{3}$ & $D^{4}$ & SEM $^{5}$ & $p$-value ${ }^{6}$ \\
\hline Number of observations & 8 & 8 & 8 & 8 & - & - \\
\hline Duration of the period, $d$ & $133^{\mathrm{bc}}$ & $145^{\text {ba }}$ & $115^{c}$ & $165^{a}$ & 7.6 & 0.001 \\
\hline \multicolumn{7}{|l|}{ Intake } \\
\hline Silage, kg dry matter (DM) $\mathrm{d}^{-1}$ & $5.43^{b}$ & $3.59^{d}$ & $6.64^{a}$ & $4.18^{\mathrm{c}}$ & 0.133 & $<0.001$ \\
\hline Barley grain, kg DM d ${ }^{-1}$ & $3.94^{\mathrm{a}}$ & $3.15^{\mathrm{b}}$ & $3.91^{\mathrm{a}}$ & $3.16^{\mathrm{b}}$ & 0.030 & $<0.001$ \\
\hline Mineral-vitamin mixture, kg DM d ${ }^{-1}$ & 0.09 & 0.09 & 0.09 & 0.09 & - & - \\
\hline Total, kg DM d ${ }^{-1}$ & $9.46^{b}$ & $6.83^{d}$ & $10.64^{a}$ & $7.43^{c}$ & 0.144 & $<0.001$ \\
\hline Silage, g DM kg-1 LW $^{0.60}$ & $129^{b}$ & $87^{d}$ & $156^{a}$ & $100^{c}$ & 3.0 & $<0.001$ \\
\hline Barley, g DM kg-1 LW $^{0.60}$ & $93^{a}$ & $76^{b}$ & $93^{a}$ & $76^{b}$ & 0.4 & $<0.001$ \\
\hline Total DM, g kg LW $^{-1} .60$ & $225^{b}$ & $165^{d}$ & $251^{a}$ & $179^{c}$ & 3.1 & $<0.001$ \\
\hline Total silage, kg DM & $722^{a}$ & $521^{b}$ & $764^{a}$ & $690^{a b}$ & 45.1 & 0.004 \\
\hline Total barley, kg DM & 524 & 457 & 450 & 521 & 29.8 & 0.291 \\
\hline Metabolisable energy (ME), $\mathrm{MJ} \mathrm{d}^{-1}$ & $108.0^{b}$ & $76.8^{d}$ & $117.9^{a}$ & $84.5^{c}$ & 1.56 & $<0.001$ \\
\hline Crude protein $(\mathrm{CP}), \mathrm{g} \mathrm{d}^{-1}$ & $1403^{b}$ & $992^{c}$ & $1575^{\mathrm{a}}$ & $1093^{b c}$ & 22.8 & $<0.001$ \\
\hline Metabolisable protein, $\mathrm{g} \mathrm{d}^{-1}$ & $807^{b}$ & $581^{d}$ & $894^{a}$ & $633^{c}$ & 11.8 & $<0.001$ \\
\hline Protein balance in the rumen, $\mathrm{g} \mathrm{d}^{-1}$ & $198^{b}$ & $124^{c}$ & $241^{a}$ & $149^{c}$ & 5.5 & $<0.001$ \\
\hline Live weight gain (LWG), $\mathrm{g} \mathrm{d}^{-1}$ & $1066^{\mathrm{b}}$ & $900^{c}$ & $1491^{\mathrm{a}}$ & $737^{d}$ & 44.7 & $<0.001$ \\
\hline \multicolumn{7}{|l|}{ Feed conversion rate } \\
\hline $\mathrm{Kg} \mathrm{DM} \mathrm{kg}^{-1}$ LWG & $8.87^{\mathrm{ab}}$ & $7.59^{b c}$ & $7.14^{\mathrm{c}}$ & $10.08^{a}$ & 0.403 & $<0.001$ \\
\hline MJ ME kg-1 LWG & $101.3^{a b}$ & $85.3^{b c}$ & $79.1^{\mathrm{c}}$ & $114.7^{a}$ & 4.54 & $<0.001$ \\
\hline g CP kg-1 LWG & $1328^{a b}$ & $1141^{b c}$ & $1089^{c}$ & $1499^{a}$ & 59.7 & $<0.001$ \\
\hline
\end{tabular}

${ }^{1} \mathrm{~A}=$ Ad libitum grass silage allowance during the whole experimental period. The amount of the barley grain supplementation was $93 \mathrm{~g} \mathrm{DM} \mathrm{kg}^{-1} \mathrm{LW}^{0.60}$ per animal per day during the whole experimental period. ${ }^{2} \mathrm{R}=$ Restricted silage and barley allowance $(0.8 \times$ treatment $A$ intake $)$ during the whole experimental period. ${ }^{3} \mathrm{I}=$ Feeding similarly as group $\mathrm{R}$ up to $430 \mathrm{~kg} \mathrm{LW}$. After that, feeding similarly as group A. ${ }^{4} \mathrm{D}=$ Feeding similarly as group $\mathrm{A}$ up to $430 \mathrm{~kg} \mathrm{LW}$. After that, feeding similarly as group R. ${ }^{5} \mathrm{SEM}$ $=$ Standard error of the mean. ${ }^{6}$ Means in the same row with different superscript letters are significantly different $(p<0.05)$. 
During the early part of the growing period DMI was restricted similarly in R and I and it was $23 \%$ lower $(p<0.05)$ compared to $A$ and $D$, which were also fed similarly. In consequence of restricted DMI, the ME, CP and MP intakes and PBV were lower in R and I $(p<0.05)$ compared to A and D.

During the late part of the growing period silage and total DMI in I were 22 and $12 \%$ higher $(p<0.05)$, respectively, compared to A. In consequence ME, CP and MP intakes and PBV were higher $(p<0.05)$ in I compared to A.

\section{Growth, feed conversion and carcass quality}

Growth rate and feed conversion rate during the whole growing period and carcass characteristics of the bulls are presented in Table 2. When the whole growing period was observed, LWG of the bulls was 37, 16 and $13 \%(p<0.05)$ and carcass gain 31,15 and $9 \%(p<0.05)$ higher in A compared to $\mathrm{R}, \mathrm{I}$ and $\mathrm{D}$, respectively. Bulls in $\mathrm{R}$ had the lowest LWG and carcass gain $(p<0.05)$. There were no significant differences in LWG and carcass gain between I and $D$.

Growth rate and feed conversion rate divided into the early and late part of growing period are presented in ables 3 and 4. During the early part of the growing period when DMI was restricted in R and I, the average LWG of these treatments was $31 \%(p<0.05)$ lower compared to the average of A and D.

During the late part of the growing period LWG in A bulls was 18 and $45 \%(p<0.05)$ higher compared to bulls in R and $D$, respectively. Bulls in I exhibited compensatory growth and LWG was $40 \%(p<0.05)$ higher compared to $A$ on the same diet during the late part of the growing period. When $D$ was compared to $R$ during the late part of the growing period, LWG was $18 \%(p<0.05)$ lower in D although they were fed similarly.

In treatments $A$ and $R$ where feeding was steady during the whole growing period, LWG decreased $214 \mathrm{~g} \mathrm{~d}^{-1}$ in A but increased $20 \mathrm{~g} \mathrm{~d}^{-1}$ in $\mathrm{R}$ during the late period compared to the early period (Fig. 1). In treatment I, LWG accelerated during the late part of the growing period as a result of compensatory growth, and was $593 \mathrm{~g} \mathrm{~d}^{-1}$ higher compared to the early period. When DMI was restricted during the late part of the growing period, LWG of bulls in $D$ decreased $558 \mathrm{~g} \mathrm{~d}^{-1}$ compared to their early period LWG (Fig. 1).

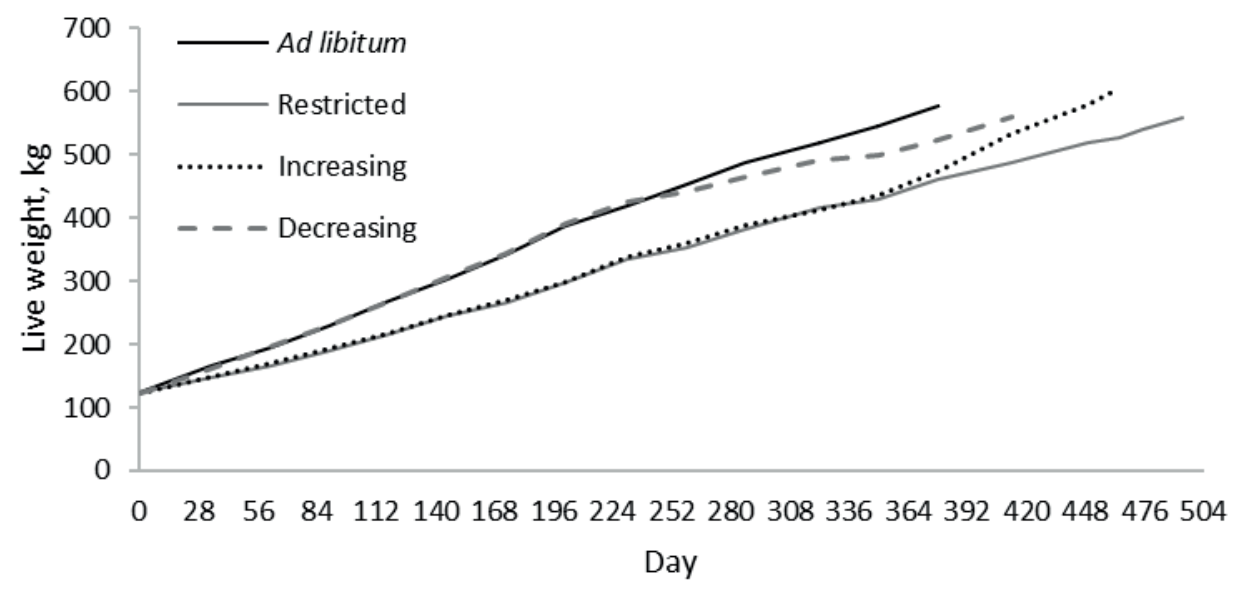

Fig. 1. Development of live weight of growing dairy bulls given four different feeding treatments, which were ad libitum feeding: silage ad libitum and barley grain $93 \mathrm{~g} \mathrm{DM} \mathrm{kg}^{-1} \mathrm{LW}^{0.60}$, restricted feeding: 0.8 $x$ treatment $A$ intake, increasing allowance: feeding similarly as group $R$ up to $430 \mathrm{~kg}$ live weight and then feeding similarly as group A and decreasing allowance: feeding similarly as group A up to 430 kg live weight and then feeding similarly as group R.

There were no significant differences among the treatments in DM, energy or CP conversion rates over the whole growing period. During the early part of the growing period, DM, energy and CP conversion rates of $A$ and D bulls were higher $(p<0.05)$ compared to bulls in $\mathrm{R}$ and I. During the late part of the growing period, DM, energy and CP conversion rates of bulls in I were significantly higher $(p<0.05)$ compared to bulls in A. Bulls in $D$ had significantly lower $(p<0.05) \mathrm{DM}$, energy and CP conversion rates than bulls in $\mathrm{R}$. 
Bulls in A were 117, 87 and 34 days younger when slaughtered $(p<0.05)$ compared to $R, I$ and $D$, respectively. Bulls in I were 53 days older $(p<0.05)$ than bulls in D. Bulls in R were the oldest at slaughter $(p<0.05)$. There were no significant differences in carcass weight, dressing proportion and carcass conformation score among the treatments. The carcass fat score of bulls in A was $29 \%$ higher $(p<0.05)$ compared to bulls in R.

\section{Discussion}

\section{Feed intake and growth}

Ad libitum silage intake improved growth rate compared to restrictively fed cattle as hypothesized. Difference in ME intake is a crucial explanation for the decreased LWG and carcass gain of R, I and D bulls compared to A bulls. It is in line with the meta-analysis of the feeding experiments by Huuskonen and Huhtanen (2015), who found that energy intake was clearly the most important variable affecting LWG of growing cattle whereas the results showed only marginal effects of protein supply on growth.

Typically, if growth rate is not manipulated by restricting intake, growth accelerates until puberty and becomes slower when approaching maturity resulting in a typical sigmoid growth curve (McDonald et al. 1988). This trend was observed in the present experiment (Fig. 1) in accordance with many earlier experiments (Knoblich et al. 1997, Rossi et al. 2001, Huuskonen et al. 2007, Huuskonen 2009, Manni et al. 2016). During the compensatory growth LWG typically increases when feed or nutrient intake increases after a restriction period, even so much that it enables animals to catch up to the weight of animals whose growth was not reduced (Hornick et al. 2000). However, restrictively fed animals rarely compensate totally and consequently require more time to reach the target slaughter weight (Coleman and Evans 1986, Hornick et al. 2000). In the present experiment, compensatory growth rate was not high enough to compensate the slower growth during the restricted period and to achieve the slaughter weight at the same time as $A$.

In the present experiment, one factor that has possibly inhibited full growth compensation was the quite long period of restricted feeding (349 days) before realimentation. According to Hornick et al. (2000), the compensatory response is improved if the duration of growth restriction is short, approximately three months in cattle, and not too severe. Typically, after refeeding the compensatory growth increases during about one month and the maximal growth lasts on average for another month then followed by decreasing growth. However, in the present experiment the growth rate continued at high level during the whole compensatory growth period (115 days) (Fig. 1).

\section{Feed conversion rate}

Contrary to our hypothesis and many other experiments (Murphy and Loerch 1994; Trial 2, Sainz et al. 1995, Rossi et al. 2001, Schmidt et al. 2005), restricted DMI did not improve feed conversion rate in the present experiment. Despite of higher DM and ME intake on treatments A and D, feed efficiency was even better compared to restricted treatments during the early part of the growing period similarly as in the experiment of Moloney et al. (2008). Restricted DMI only during the late part of the growing period may even impair feed efficiency, as was the case in the present experiment and also in the experiment of Moloney et al. (2008).

In the present experiment, bulls in I during the late part of the growing period had higher DMI, LWG and feed efficiency compared to $A$. Reasons for this may be reduction in energy density of tissue growth, reduction in maintenance energy requirements, increase in the net efficiency of tissue growth and increase in feed intake and subsequent gut fill, which all are found to be related to compensatory growth (Carstens 1995). Consistent with the present experiment, improved feed efficiency has found to be related to compensatory growth in earlier experiments (Sainz et al. 1995, Keogh et al. 2015). When comparing I to R during the late part of the growing period, there were no differences in feed efficiency although LWG of bulls in R was significantly lower.

Typically, feed conversion is more efficient in young animals and declines as cattle approach maturity and growth rate declines. This trend was observed in the present experiment in the steadily fed groups $A$ and $R$, consistently with many other experiments (Keane 2010, Manni et al. 2013, Manni et al. 2016). 


\section{Carcass quality}

According to Hornick et al. (2000), it is expected that reduced growth rate results in leaner carcasses because fat deposition is affected more than protein deposition. This effect was not found in the present experiment and effects of growth restriction on carcass composition vary between experiments (Hicks et al. 1990, Sainz et al. 1995, Schmidt et al. 2005). Contrary to what we hypothesized and the conclusion of Huuskonen and Huhtanen (2015), ME intake did not improve carcass conformation in the present experiment. Increased deposition of protein relative to fat has been identified as a mechanism contributing to compensatory growth (Ryan 1993). However, in the present experiment, Knoblich et al. (1997) and Rossi et al. (2001), compensatory growth did not affect carcass conformation.

It is generally agreed that increased energy intake of growing cattle increases carcass fatness (Nogalski et al. 2014, Huuskonen and Huhtanen 2015), which is in line with the current results when comparing A to R. However, restricted energy intake only during the late part of the growing did not affect fatness. The result is consistent with the experiment of Steen and Kilpatrick (2000), who concluded that reducing slaughter weight is the most effective strategy to reduce carcass fatness. In many experiments, carcass fatness has tended to increase with increasing growth rate (Keane et al. 2006, Herva et al. 2011, Manni et al. 2013, Manni et al. 2016). Similarly, in the present experiment carcass fatness increased numerically with increasing growth rate. However, Owens et al. (1995) found that mass of fat increased quadratically with weight whereas protein mass increased more linearly and changes in body composition do not depend on rate of gain but on degree of maturity.

Restricted feeding reduced carcass fatness according to our hypothesis. Decreased carcass fatness is also a general expectation of the compensatory growth phenomenon (Carstens et al. 1991, Wright and Russel 1991, Carstens 1995, Keogh et al. 2015), but this effect was not found in the present experiment. According to earlier experiments, these effects vary (Tudor et al. 1980, Abdalla et al. 1988, Hornick et al. 2000, Moloney et al. 2008). The conflicting results may originate partly from differences in severity and duration of the growth restriction, duration of refeeding and genetic background of the animals (Hornick et al. 2000).

\section{Conclusions}

As hypothesized, the present experiment indicates that ad libitum silage intake supplemented with concentrate resulted in fastest growth and decreased the length of the growing period of dairy bulls compared to the restricted feeding strategies but increased carcass fatness. Contrary to our hypothesis, restricted feeding did not improve the feed conversion rate compared to unrestricted feeding. Therefore, the present experiment indicates that grass silage intake ad libitum supplemented with concentrate is a method to produce beef efficiently under Northern European conditions.

Increasing and decreasing feeding strategies resulted in different growth patterns as hypothesized but did not affect the average growth rate of the bulls. Usefulness of different restricted feeding strategies depends on many factors the most important being feed prices, availability and quality. If there is a temporary lack in the amount and/or quality of feeds offered, it does not necessarily have major harmful consequences on beef production.

\section{Acknowledgements}

We wish to express our gratitude to Mr. Matti Huumonen and his personnel for technical assistance and excellent care of the experimental animals.

\section{References}

Abdalla, H.O., Fox, D.G. \& Thonney, M.L. 1988. Compensatory gain by Holstein calves after underfeeding protein. Journal of Animal Science 66: 2687-2695. https://doi.org/10.2527/jas1988.66102687x

Carstens, G.E. 1995. Compensatory growth in beef cattle. In: Proceedings of a Symposium: Intake by Feedlot Cattle. Oklahoma, Agricultural Experiment Station. p. 70-84.

Carstens, G.E., Johson, D.E., Ellenberger, M.A. \& Tatum, J.D. 1991. Physical and chemical components of the empty body during compensatory growth in beef steers. Journal of Animal Science 69: 3251-3264. https://doi.org/10.2527/1991.6983251x

Coleman, S.W. \& Evans, B.C. 1986. Effect of nutrition, age and size on compensatory growth in two breeds of steers. Journal of Animal Science 63: 1968-1982. https://doi.org/10.2527/jas1986.6361968x 
EC 2006. Council Regulation (EC) No 1183/2006 of 24 July 2006 concerning the Community scale for the classification of carcasses of adult bovine animals. The Official Journal of the European Union L214: 1-6.

French, P., O'Riordan, E.G., Moloney, A.P., O'Kiely, P. \& Caffrey, P.J. 2001a. Effects of concentrate level and grazing system on the performance of beef cattle grazing autumn herbage. Irish Journal of Agricultural and Food Research 40: 33-44.

French, P., O'Riordan, E.G., O'Kiely, P., Caffrey, P.J. \& Moloney, A.P. 2001b. Intake and growth of steers offered different allowances of autumn grass and concentrates. Animal Science 72: 129-138. https://doi.org/10.1017/S1357729800055624

Herva, T., Huuskonen, A., Virtala, A-M. \& Peltoniemi, O. 2011. On-farm welfare and carcass fat score of bulls at slaughter. Livestock Science 138: 159-166. https://doi.org/10.1016/j.livsci.2010.12.019

Hicks, R.B., Owens, F.N., Gill, D.R. Martin, J.J. \& Strasia, C.A. 1990. Effects of controlled feed intake on performance and carcass characteristics of feedlot steers and heifers. Journal of Animal Science 68: 233-244.

Hornick, J.L., Van Eenaeme, C., Gérard, O., Dufrasne, I. \& Istasse, L. 2000. Mechanisms of reduced and compensatory growth. 2000. Domestic Animal Endocrinology 19: 121-132. https://doi.org/10.1016/S0739-7240(00)00072-2

Huhtanen, P., Nousiainen, J. \& Rinne, M. 2006. Recent developments in forage evaluation with special reference to practical applications. Agricultural and Food Science 15: 293-323.

Huida, L., Väätäinen, H. \& Lampila, M. 1986. Comparison of dry matter contents in grass silage as determined by oven drying and gas chromatographic water analysis. Annales Agriculturae Fenniae 25: 215-230.

Huuskonen, A. 2009. The effect of cereal type (barley versus oats) and rapeseed meal supplementation on the performance of growing and finishing dairy bulls offered grass silage-based diets. Livestock Science 122: 53-62.

https://doi.org/10.1016/j.livsci.2008.07.023

Huuskonen, A. \& Huhtanen, P. 2015. The development of a model to predict weight gain of growing cattle fed grass silage-based diets. Animal 9: 1329-1340. https://doi.org/10.1017/S1751731115000610

Huuskonen, A., Khalili, H. \& Joki-Tokola, E. 2007. Effects of three different concentrate proportions and rapeseed meal supplement to grass silage on animal performance of dairy-breed bulls with TMR feeding. Livestock Science 110: 154-165. https://doi.org/10.1016/j.livsci.2006.10.015

Keane, M.G. 2010. A comparison of finishing strategies to fixed slaughter weights for Holstein Friesian and Belgian Blue $\mathrm{x}$ Holstein Friesian steers. Irish Journal of Agricultural and Food Research 49: 41-54.

Keane, M.G., Drennan, M.J. \& Moloney, A.P. 2006. Comparison of supplementary concentrate levels with grass silage, separate or total mixed ration feeding, and duration of finishing in beef steers. Livestock Science 103: 169-180. https://doi.org/10.1016/j.livsci.2006.02.008

Keogh, K., Waters, S.M., Kelly, A.K. \& Kenny, D.A. 2015. Feed restriction and subsequent realimentation in Holstein Friesian bulls: Effect on animal performance; muscle, fat, and linear body measurements; and slaughter characteristics. Journal of Animal Science 93: 3578-3589. https://doi.org/10.2527/jas.2014-8470

Knoblich, H.V., Fluharty, F.L. \& Loerch, S.C. 1997. Effects of programmed gain strategies on performance and carcass characteristics of steers. Journal of Animal Science 75: 3094-3102. https://doi.org/10.2527/1997.75123094x

Luke 2017. Feed tables and nutrient requirements. http://www.luke.fi/feedtables. Accessed 1 January 2017.

MAFF 1984. Energy Allowances and Feeding Systems for Ruminants. ADAS Reference book 433. Ministry of Agriculture, Fisheries and Food. Her Majesty's Stationery Office, London. 85 p.

Manni, K., Rinne, M. \& Huhtanen, P. 2013. Comparison of concentrate feeding strategies for growing dairy bulls. Livestock Science 152: 21-30. https://doi.org/10.1016/j.livsci.2012.12.006

Manni, K. Rinne, M. \& Huuskonen, A. 2016. Effects of barley intake and allocation regime on performance of growing dairy bulls offered highly digestible grass silage. Livestock Science 191: 72-79. https://doi.org/10.1016/j.livsci.2016.07.004

McDonald, P., Edwards, R.A. \& Greenhalgh, J.F.D. 1988. Animal Nutrition. 4th ed. Singapore: Longman Singapore Publishers. 543 p.

Moisio, T. \& Heikonen, M. 1989. A titration method for silage assessment. Animal Feed Science and Technology 22: 341-353. https://doi.org/10.1016/0377-8401(89)90078-3

Moloney, A.P., Keane, M.G., Dunne, P.G., Mooney, M.T. \& Troy, D.J. 2008. Effect of concentrate feeding pattern in a grass silage/ concentrate beef finishing system on performance, selected carcass and meat quality characteristics. Meat Science 79: 355-364. https://doi.org/10.1016/j.meatsci.2007.10.018

Murphy, T.A. \& Loerch, S.C. 1994. Effects of restricted feeding of growing steers on performance, carcass characteristics, and composition. Journal of Animal Science 72: 2497-2507.

Nogalski, Z., Wielgosz-Groth, Z., Purwin, C., Nogalska, A., Sobczuk-Szul, M., Winarski R. \& Pogorzelska, P. 2014. The effect of slaughter weight and fattening intensity on changes in carcass fatness in young Holstein-Friesian bulls. Italian Journal of Animal Science 13: 66-72. https://doi.org/10.4081/ijas.2014.2824

Owens, F.N., Gill, D.R., Secrist, D.S. \& Coleman, S.W. 1995. Review of some aspects of growth and development of feedlot cattle. Journal of Animal Science 73: 3152-3172. https://doi.org/10.2527/1995.73103152x

Rompala, R.E., Jones, S.D.M., Buchanan-Smith, J.G. \& Bayley, H.S. 1985. Feedlot performance and composition gain in latematuring steers exhibiting normal and compensatory growth. Journal of Animal Science 61: 637-646. https://doi.org/10.2527/jas1985.613637x

Rossi, J.E., Loerch, S.C., Moeller, S.J. \& Schoonmaker, J.P. 2001. Effects of programmed growth rate and days fed on performance and carcass characteristics of feedlot steers. Journal of Animal Science 79: 1394-1401. https://doi.org/10.2527/2001.7961394x

Ryan, W.J., Williams, I.H. \& Moir, R.J. 1993. Compensatory growth in sheep and cattle, II. Changes in body composition and tissue weights. Australian Journal of Agricultural Research 44: 1623-1633. https://doi.org/10.1071/AR9931623 
Sainz, R.D., de la Torre, F. \& Oltjen, J.W. 1995. Compensatory growth and carcass quality in growth-restricted and refed beef steers. Journal of Animal Science 73: 2971-2979. https://doi.org/10.2527/1995.73102971x

Schmidt, T.B., Olson, K.C., Pas, Linville, M.L., Clark, J.H., Meyer, D.L., Brandt, M.M., Stahl, C.A., Rentfrow, G.K. \& Berg, E.P. 2005. Effects of dry matter intake restriction on growth performance and carcass merit of finishing steers. The Professional Animal Scientist 21: 332-338. https://doi.org/10.15232/S1080-7446(15)31224-9

Steen, R.W.J. \& Kilpatrick, D.J. 2000. The effects of the ratio of grass silage to concentrates in the diet and restricted dry matter intake on the performance and carcass composition of beef cattle. Livestock Production Science 62: 181-192. https://doi.org/10.1016/S0301-6226(99)00057-3

Tudor, G.D., Utting, D. \& O'Rourke, P. 1980. The effect of pre- and post-natal nutrition on the growth of beef cattle. III The effect of severe restriction in early post-natal life on development of body components and chemical composition. Australian Journal of Agricultural Research 31: 191-204. https://doi.org/10.1071/AR9800191

Van Soest, P.J., Robertson, J.B. \& Lewis, B.A. 1991. Methods for dietary fiber, neutral detergent fiber, and nonstarch polysaccharides in relation to animal nutrition. Journal of Dairy Science 74: 3583-3597. https://doi.org/10.3168/jds.S0022-0302(91)78551-2

Wright, I.A. \& Russel, A.J.F. 1991. Changes in the body composition of beef cattle during compensatory growth. Animal Production 52: 105-113. https://doi.org/10.1017/S0003356100005730 